\title{
ANALISIS FAKTOR-FAKTOR YANG BERPENGARUH TERHADAP KETERANDALAN DAN KETEPATWAKTUAN PELAPORAN KEUANGAN BERBASIS AKRUAL PADA PEMDA KKT
}

\author{
Sukriyadi \\ Sekolah Tinggi Ilmu Ekonomi Saumlaki, sukriyadiucky@gmail.com
}

\begin{abstract}
This study aims to test the factors that influence reliability and timeliness of local government financial reporting. The factors that influence reliability and timeliness are commitment organization, human resource capacity, Internal Control of Accounting, information technology utilization, regional financial oversight, and the implementation of government accounting standards (SAP) to the reliability and timeliness of local government financial reporting accrual basis in SKPD Kepulauan Tanimbar regency.

This research was a quantitative research study. amounting to 130 people, The was processed using SPSS with multiple linier regressions.

Based on the analysis results, obtained that the commitment organization, human resource capacity, regional financial oversight, and the implementation of government accounting standards (SAP) influential in raising the reliability and timeliness of the financial reporting accrual basis in SKPD, with a significance level of $0.000<0.05$. While on the analysis results internal control of accounting, and information technology utilization no affect significant on reliability and timeliness of local government financial reporting.
\end{abstract}

Key words : Commitment organization, human resource capacity, Internal Control of Accounting, information technology utilization, regional financial oversight, government accounting standards (SAP), reliability and timeliness

\section{Pendahuluan}

Akuntabilitas sektor publik saat ini telah penyimpangan yang berhasil mendapat banyak perhatian seiring dengan ditemukan oleh Badan Pemeriksa Keuangan banyaknya penyimpangan(BPK) dalam pelaksanaan audit laporan 
keuangan pemerintah daerah. Pemerintah telah mengeluarkan berbagai peraturan perundang-undangan yang telah mengalami banyak pembaharuan, diantaranya UU No.17 Tahun 2003 tentang Keuangan Negara, serta PP No.71 tahun 2010 yang pada dasarnya menjadi standar dan acuan dalam pelaporan keuangan daerah terhadap penyelenggaran pemerintah yang baik (good governance). Oleh karena itu, pemerintah mengharapkan pegawai dan seluruh stakeholders dapat membantu dalam penerapan SAP berbasis akrual agar penyajian laporan keuangan lebih transparan dan lebih akuntabel.

Organisasi pemerintahan merupakan bagian dari sektor non bisnis, Jones Pendlebury (2010), namun pernyataan tersebut tidak akan berhasil jika organisasi pemerintah berorientasi pada tujuan memaksimumkan laba (profit oriented) dan memihak kepada kepentingan pribadi aparaturnya bukan untuk kepentingan umum dan pelayanan kepada masyarakat. Hal ini secara langsung dapat membantu pimpinan dalam pengambilan keputusan untuk mencapai tujuan organisasinya (Reynolds 2012).
Pemerintah daerah wajib memperhatikan informasi yang disajikan dalam laporan keuangan untuk keperluan perencanaan, pengendalian, dan pengambilan keputusan. Informasi akuntansi harus mempunyai beberapa karakteristik kualitatif yang disyaratkan antara lain : (1) Relevan, (2) Andal, (3) Dapat dibandingkan, (4). Dapat dipahami. (PP Nomor 71 Tahun 2010)

Dari karakteristik kualitatif laporan keuangan pemerintah tersebut, ketepatwaktuan dan keterandalan merupakan dua unsur nilai informasi yang penting terkait dengan pengambilan keputusan berbagai pihak. Ketepatwaktuan merupakan tersedianya informasi bagi pembuat keputusan saat dibutuhkan sedangkan Keterandalan merupakan kemampuan informasi untuk memberi keyakinan benar atau valid. (PP.71 tahun 2010).

Dalam hal tertentu, mengejar keberpautan dan ketepatwaktuan untuk mencapai kebermanfaatan harus dibarengi dengan mengorbankan kualitas lain yaitu keakuratan/presisi (accuracy/precision) atau keterandalan. Jadi terdapat saling korban (trade-off) antara ketepatwaktuan dan 
keterandalan/reliabilitas untuk mendapatkan kebermanfaatan. Namun, berkurangnya reliabilitas berakibat berkurangnya kebermanfaatan, dimungkinkan untuk mempercepat ketersediaan data secara aproksimasi tanpa mempengaruhi reliabilitas secara material. Dengan begitu ketepatwaktuan dengan aproksimasi justru akan meningkatkan kebermanfaatan secara keseluruhan (KDP2LK, 2015).

Keterandalan dapat terwujud jika unsur normatif ketepatwaktuan dimasukkan dalam penyampaian laporan keuangan, untuk dukungan kedua hal ini (Reliability and Timeliness) harus dikaitkan walaupun adanya trade-off yang mengurangi kebermanfaatan, dimungkinkan untuk mempercepat ketersediaan data secara aproksimasi (pengukuran, penimbangan, dan penakaran) tanpa mempengaruhi reliabilitas secara material. Dengan begitu ketepatwaktuan dengan aproksimasi justru akan meningkatkan kebermanfaatan informasi dalam laporan keuangan secara keseluruhan (Weygandt, Keiso et al, 2011).

Tantangan keberhasilan dalam penyajian laporan keuangan basis akrual yang andal dan tepat waktu dipengaruhi beberapa faktor penting diantaranya : 1) Komitmen Organisasi, 2). Kapasitas Sumber Daya Manusia, 3). Pemanfaatan Teknologi Informasi, 4). Pengendalian Internal Akuntansi, 5). Pengawasan Keuangan Daerah, dan 6). Standar Akuntansi Pemerintahan.

Penelitian tentang keterandalan dan ketepatwaktuan laporan keuangan sangat menarik untuk diteliti kembali karena penelitian terdahulu belum memasukkan basis akrual, kuranglah jumlah variabel yang dinilai dalam mempengaruhi keterandalan dan ketepatwaktuan laporan keuangan serta beberapa hasil yang tidak konsisten dari para peneliti sebelumnya diantaranya penelitian Diawati (2015) tentang faktor yang berpengaruh terhadap keterandalan laporan keuangan menemukan bahwa pengendalian internal akuntansi dan pemanfaatan teknologi informasi tidak berpengaruh terhadap keterandalan laporan keuangan, hasil tersebut berlawanan dengan penelitian Primayana (2014), Desmiyawati (2014), Sari (2014), Eriesta (2013), Hullah (2012), Arfianti (2011), Rosalin (2011), dan Andriani 
(2010), dimana pengendalian internal akuntansi dan pemanfaatan teknologi informasi berpengaruh positif terhadap keterandalan dan ketepatwaktuan penyajian laporan keuangan.

Dari uraian diatas kebanyakan peneliti tidak memasukkan variabel komitmen organisasi dalam penelitiannya, satu-satunya yang meneliti adalah Rosalin (2011), dalam temuannya menyatakan bahwa komitmen organisasi berpengaruh signifikan terhadap keterandalan dan timeliness pelaporan keuangan, pemanfaatan teknologi, pengendalian intern akuntansi, Sedangkan kualitas SDM tidak berpengaruh signifikan terhadap keandalan dan timeliness pelaporan keuangan. Komitmen Organisasi tersebut adalah sikap kesediaan diri dalam melaksanakan tugas (Hellrieger \& Slocum 13 ${ }^{\text {th }}$ 2011).

Penelitian sebelumnya hampir semua menunjukkan hasil yang tidak sama atau tidak konsisten antara variabel-variabel yang dinilai dalam mempengaruhi keterandalan dan ketepatwaktuan pelaporan keuangan seperti sumber daya manusia yang diteliti oleh Rosalin (2011), menemukan bukti empiris bahwa tidak signifikan sedangkan peneliti lainnya seperti penelitian Primayana (2014), menemukan hal yang berbeda bahwa kapasitas sumber daya manusia, berpengaruh positif terhadap keterandalan laporan keuangan.

Lain halnya Standar Akuntansi Pemerintahan (SAP), dimana PP. 71 tahun 2010 semua pemerintah daerah sudah harus menerapkan accrual basic. Peneliti sebelumnya (Diawati;2015), Standar Akuntansi Pemerintahan berpengaruh positif terhadap keterandalan laporan keuangan daerah pemerintahan Kota Surakarta. Hal ini karena pemerintah masih menggunakan cash basic menuju accrual basic. Tantangan kedepan penerapan full accrual basic sesuai amanat PP. No. 71 tahun 2010, apakah prinsip-prinsip standar akuntansi pemerintahan tersebut sudah diterapkan oleh entitas pelapor (SKPD) dengan baik untuk mendukung keterandalan dan ketepatwaktuan pelaporan keuangan pemerintah daerah ?. Dengan demikian penelitian ini menganalisis dan menggabungkan beberapa variabel yang dianalisis terpisah pada penelitian sebelumnya, agar dapat menyimpulkan bagaimana faktor-faktor tersebut 
berpengaruh terhadap keterandalan dan ketepatwaktuan pelaporan keuangan berbasis akrual pada pemerintah daerah kabupaten Kepulauan Tanimbar.

\section{METODE PENELITIAN}

\section{Ruang Lingkup dan Desain Penelitian}

Penelitian ini menggunakan teknik survei dari beberapa sampel anggota populasi yang datanya telah dikumpulkan dengan menggunakan kuesioner (Sekaran, 2003). Jenis penelitian ini disebut deskriptif verifikatif (Casual) yang bertujuan mengetahui hubungan kausalitas antara variabel melalui pengujian hipotesis. (Sugiyono (2010:29), sedangkan metode verifikatif bertujuan menguji hubungan antar variabel secara matematis dari hipotesis masalah yang sedang diselidiki, apakah diterima atau ditolak.

\section{Desain Variabel Penelitian dan Indikator}

Pembatasan variabel yang digunakan dan subjek yang diteliti antara lain :

1) Komitmen Organisasi 3 (tiga) indikator;

2) Kapasitas SDM 3 (tiga) indikator;

3) P.I. Akuntansi 4 (empat) indikator;

4) Pemanfaatan TI 3 (tiga) indikator;

5) Pengawasan KEUDA 4 (empat) indikator;

6) SAP terdiri dari 4 (empat) indikator;

7) Keterandalan dan Ketepatwaktuan terdiri dari 7 (tujuh) indikator

Sumber : Arfianti (2011), Zuliarti (2012), Eriesta (2013), Primayana, (2014), Diawati (2015).

\section{Lokasi Penelitian}

Penelitian ini akan dilaksanakan pada setiap Satuan Kerja Perangkat Daerah (SKPD) yang meliputi seluruh Dinas, Badan, Bagian, Kantor, dan Rumah Sakit, yang berlokasi di Saumlaki - Kabupaten Kepulauan Tanimbar.

\section{Populasi dan Sampel}

Populasi dari Penelitian ini adalah Aparatur Sipil Negara (ASN) yang berjumlah 2.014 dari 38 satuan Kerja Perangkat Daerah 
(SKPD) pada Pemerintah Daerah Kabupaten Kepulauan Tanimbar, dengan pengambilan sampel sebanyak 152 orang yang memadai dan cukup dalam mewakili populasinya yaitu 1) Bendahara Pengeluaran, 2) Kasubag. Keuangan selaku Verifikator keuangan, 3) PPK selaku auditor internal (jabatan Fungsional/atau Sekretaris), 4) dan Pengguna Anggaran (PA).

Pengambilan sampel menggunakan purposive / judgement sampling. Kriteria responden adalah para ASN sehingga tiap SKPD ditetapkan secara cluster sampling sebanyak 4 orang. Purposive sampling digunakan karena informasi yang akan diambil dari sumber yang sengaja dipilih berdasarkan kriteria yang telah ditetapkan peneliti (Sekaran, 2003).

\section{Pengumpulan Data}

Data yang dihimpun dalam penelitian ini meliputi dua macam data, yaitu data primer dan data sekunder. Adapun teknik dilakukan yaitu :

1) Kuisioner berupa daftar pertanyaan yang disajikan kepada responden untuk memperoleh data deskriptif dalam menguji hipotesis dan responden dibatasi dalam memberikan jawaban pada alternatif atau pada satu jawaban saja (Nasir, 2005:152). Item skala penilaian disusun berdasarkan Skala Likert. Skor yang dipakai adalah 5, 4, 3, 2, 1 yang diterapkan secara bervariasi sesuai kategori pertanyaan.

2) Dokumentasi untuk mendapatkan data skunder dan data primer dilakukan untuk mempelajari dokumen-dokumen resmi/arsip yang tertulis yang relevan seperti bagan struktur organisasi, jumlah karyawan/pegawai, dokumen keuangan dan lain sebagainya yang terdapat dilokasi penelitian.

\section{Teknik Analisis Data}

\section{Analisis Deskriptif}

Metode ini digunakan dengan tujuan untuk memperoleh gambaran tentang kondisi karakteristik variabel terikat serta untuk mengidentifikasikan karakteristik masing-masing variabel dalam bentuk frekwensi dan presentase. Analisis ini diperlukan untuk mendeskripsikan atau menggambarkan data hasil pengumpulan kuesioner.

\section{Uji Validitas Instrumen}


Menurut Sugiono (2010) untuk menguji validitas dilakukan dengan cara mengkorelasikan antara skor butir pertanyaan dengan skor totalnya.

Rumus yang digunakan untuk menguji validitas instrumen ini adalah Product Moment dari Karl Pearson, dengan level signifikansi 5\% dari nilai kritisnya, dimana $r$ dapat digunakan rumus (Arikunto,2010:59)

Sebagai berikut :

\section{Keterangan :}

$\mathrm{n}$ = banyaknya sampel (responden)

$\mathrm{X}=$ Skor total item $\mathrm{X}$

$\mathrm{Y}=$ Skor nilai item $\mathrm{Y}$

Bila $r_{x y}$ lebih besar dari nol dengan nilai signifikansi probabilitas $\mathrm{P}$ kurang dari 0,05 (atau 5\%) maka instrumen penelitian masuk dalam kategori valid dan sebaliknya dinyatakan tidak valid.

\section{Uji Reliabilitas Instrumen}

Arikunto (2010:

menyatakan "Reliabilitas menunjuk pada suatu pengertian bahwa sesuatu instrumen dapat dipercaya untuk digunakan sebagai alat pengumpul data karena instrumen sudah baik"
Uji reliabilitas dilakukan dengan rumus cronbach alpha sebagai berikut:

$$
r_{11}=\left[\frac{k}{(k-1)}\right]\left[1-\frac{\sum \sigma_{b}^{2}}{\sigma_{t}^{2}}\right]
$$

Keterangan :

$\mathrm{r}_{11}=$ realibilitas instrumen

$\mathrm{k}$ = banyaknya butir pertanyaan atau banyaknya soal

$\sigma_{b}^{2}=$ jumlah varians butir

$\sigma_{t}^{2}=$ varians total

Instrumen dapat dikatakan andal (reliable bila memiliki koefisien keandalan realibilitas sebesar 0,6 (60\%) atau lebih. Arikunto (2010:57)

$r_{x y}=\frac{N \sum X Y-\left(\sum X\right)\left(\sum Y\right)}{\sqrt{\left\{N \sum X^{2}-\left(\sum X\right)^{2}\right\}\left\{N \sum Y^{2}-\left(\sum Y\right)^{2}\right\}}}$

Uji Realibilitas yang digunakan adalah Alpha Cronbach, jika Cronbach Alpha $\left(\mathrm{r}_{11}\right)$ lebih kecil dari < 0,6 maka dinyatakan tidak reliabel dan sebaliknya dinyatakan reliabel.

\section{Analisis Regresi Liner Berganda}

Metode ini digunakan dengan tujuan untuk menguji pengaruh sebab akibat antara variabel bebas (X) terhadap variabel terikat (Y). Statistik inferensial yang digunakan dalam analisis data adalah menggunakan analisis regresi. Persamaan yang digunakan (sugiyono; 2012) yaitu:

$$
\begin{aligned}
& Y=a+\beta_{1} X 1+\beta_{2} X 2+\beta_{3} X 4+\beta_{4} X 4+\beta_{5} X 5 \\
& +\beta_{6} X 6+e
\end{aligned}
$$


dimana :

Y1 : Keterandalan \& Ketepatwaktuan

X1 : Komitmen Organisasi

X2 : Kapasitas SDM

X3 : Pengend. Intern Akuntansi

X4 : Pemanfaatan Teknologi

X5 : Pengawasan Keuangan Daerah

X6 : Standar Akuntansi Pemerintah

$\beta_{1} \ldots . . \beta_{8}$ : Intercept/koefisien regresi

E : Error

$\alpha \quad$ : Kostanta

\section{Uji Asumsi Klasik}

Pengujian statistik dengan analisis regresi dapat dilakukan dengan pertimbangan tidak adanya pelanggaran terhadap asumsi klasik. Untuk menilai setiap variabel bebas maka perlu memenuhi asumsi - asumsi klasik agar diperoleh hasil yang tidak bias atau dengan kata lain untuk mengetahui apakah estimator-estimator pengujian tersebut bersifat BLUE (Best Linier Unbias Estimator) atau tidak. (ghozali, 2011). Asumsi tersebut adalah:

a. Uji Multikolinearitas b. Uji Heterokedasitas

c. Uji Autokorelasi

d. Uji Normalitas

\section{Pengujian Hipotesis}

\section{a. Koefisien Diterminasi}

Koefisien diterminasi $\left(\mathrm{R}^{2}\right)$ bertujuan untuk mengukur seberapa jauh kemampuan model dapat menerangkan variasi variabel dependen. Nilai koefisien determinasi adalah antara 0 (nol) dan 1 (satu). Nilai $\mathrm{R}^{2}$ yang kecil berarti kemampuan variabel-variabel independen dalam menjelaskan variasi variabel dependen amat terbatas. (Ghozali,2011: 87).

\section{b. Uji F (over all test)}

Uji statistik F (F-test) atau uji simultan digunakan untuk mengetahui apakah variabel-variabel independen yang dimasukkan dalam model mempunyai pengaruh secara bersamasama atau simultan terhadap variabel dependen. (Ghozali,2011: 89).

Pengujian menggunakan Uji F dengan rumus sebagai berikut : 


$$
\begin{aligned}
& \mathbf{F}=\frac{\mathbf{R}^{2} / \mathbf{k}}{\left(\mathbf{1}-\mathbf{R}^{2}\right) /(\mathbf{n}-\mathbf{k}-\mathbf{1})} \\
& \mathrm{R}^{2}=\text { Koefisien determinasi } \\
& \mathrm{n}=\text { Jumlah sampel } \\
& \mathrm{k}=\text { jumlah variabel bebas digunakan } \\
& \text { dalam model regresi }
\end{aligned}
$$

Uji $\mathrm{t}$ dipakai untuk melihat signifikansi dari pengaruh independen secara individu terhadap variabel dependen dengan menganggap variabel lain bersifat konstan (Ghozali,2011: 88). Uji t dengan rumus:

$$
\mathrm{t}=\frac{\mathrm{r} \sqrt{\mathrm{n}-2}}{\sqrt{1-r^{2}}} \text { atau }_{t_{\text {hitung }}}=\frac{r_{x y} \sqrt{(n-2)}}{\sqrt{\left(1-r_{x y^{2}}\right)}}
$$

dimana :

$\mathrm{r}=$ nilai koefisien korelasi

$\mathrm{n}=$ Jumlah responden, (n-2=dk, derajat kebebasan)

$\mathrm{t}=$ nilai $\mathrm{t}$ hitung

atau : mengetahui berapa persen pengaruh variabel bebas $(\mathrm{X})$ yang dimasukkan dalam model mempengaruhi variabel tergantung $(\mathrm{Y})$.

\section{c. Uji t (individu test)}

\section{HASIL DAN PEMBAHASAN}

\section{Hasil Penelitian}

\section{Deskriptif Data}

Statistik deskriptif mempunyai tujuan untuk memberikan gambaran mengenai variabel-variabel penelitian. Hasil analisis deskriptif dengan menggunakan bantuan program SPSS adalah sebagai berikut: 
kerja perangkat daerah (SKPD) yang lain.

\section{Uji Validitas dan Reliabilitas}

Tabel 4.7

Hasil Analisis Deskriptif Statistik

Descriptive Statistics

\begin{tabular}{|l|r|r|r|r|r|r|}
\hline & \multicolumn{1}{|c|}{$\mathrm{N}$} & Minimum & Maximum & \multicolumn{1}{c|}{ Sum } & \multicolumn{1}{c|}{ Mean } & Std. Deviation \\
\hline Komitmen Organisasi & 130 & 38 & 58 & 6391 & 49.16 & 4.048 \\
Kapasitas SDM & 130 & 16 & 49 & 4459 & 34.30 & 8.181 \\
$\begin{array}{l}\text { Pengendalian Internal } \\
\text { Akuntansi }\end{array}$ & 130 & 32 & 50 & 5465 & 42.04 & 4.186 \\
$\begin{array}{l}\text { Pemanfaatan Teknologi } \\
\text { Informasi }\end{array}$ & 130 & 29 & 50 & 5370 & 41.31 & 4.428 \\
$\begin{array}{l}\text { Pengawasan Keuangan } \\
\text { Daerah }\end{array}$ & 130 & 37 & 60 & 6517 & 50.13 & 4.855 \\
$\begin{array}{l}\text { Standar Akuntansi } \\
\text { Pemerintahan }\end{array}$ & 130 & 39 & 60 & 6491 & 49.93 & 4.883 \\
Keterandalan Dan & 130 & 51 & 85 & 8969 & 68.99 & 6.633 \\
Ketepatwaktuan & 130 & & & & & \\
Valid N (listwise) & & & & & & \\
\hline
\end{tabular}

Sumber data : Data primer yang diolah 2020 (Output SPSS)

Berdasarkan tabel 4.7 maka dapat diketahui bahwa jumlah data penelitian $(\mathrm{N})$ adalah sebesar 130 data kuesioner yang kembali dari 152 yang tersebar. Nilai variabel-variabel tersebut dapat dilihat bahwa masing-masing mempunyai nilai minimum, maksimum, rata-rata dengan nilai standar deviasi yang berbeda. Nilai standar deviasi yang lebih kecil dibandingkan nilai rata-ratanya mengandung arti bahwa masing dari 7 (tujuh) variable tersebut pada satuan kerja perangkat daerah kabupaten Kepulauan Tanimbar tidak jauh berbeda antara satuan

\section{a. Uji Validitas}

Pengujian validitas instrumen menggunakan metode Korelasi Product Moment yaitu dengan membandingkan nilai koefiesian korelasi antara butir pernyataan dengan total jawaban ( $\mathrm{r}$ hitung) dengan nilai ( $\mathrm{r}$ table) pada tingkat kesalahan (alpha) tertentu. Jika nilai $\mathrm{r}$ hitung lebih besar dari $\mathrm{r}$ tabel maka butir pernyataan yang digunakan adalah valid atau jika nilai signifikansi lebih kecil dari alpha, maka butir pernyataan yang digunakan adalah valid.

Uji validitas dengan program SPSS diperoleh hasil sebagai berikut:

Tabel 4.8 (14)

Hasil Analisis Validitas

\begin{tabular}{|c|c|c|c|c|c|c|c|c|c|}
\hline \multirow[b]{2}{*}{$\begin{array}{l}\text { Butir/Point } \\
\text { Pertanyaan }\end{array}$} & \multicolumn{7}{|c|}{ Variabel Koefisien Korelasi (r - hitung) } & \multirow[b]{2}{*}{$\mathrm{r}$-Tabel } & \multirow[b]{2}{*}{ Ket } \\
\hline & $\begin{array}{c}\text { Komitme } \\
\text { n } \\
\text { Organisa } \\
\text { si (X1) } \\
\\
\text { (12 Item) }\end{array}$ & $\begin{array}{l}\text { Kapasitas } \\
\text { SDM } \\
(\mathrm{X} 2) \\
\\
(10 \mathrm{Item})\end{array}$ & $\begin{array}{l}\text { Pengendali } \\
\text { an Internal } \\
\text { Akuntansi } \\
\text { (X3) } \\
\\
\text { (10 Item) }\end{array}$ & $\begin{array}{c}\text { Pemanfaata } \\
n \\
\text { Teknologi } \\
\text { Informasi } \\
\text { (X4) } \\
\\
\text { (10 Item) }\end{array}$ & $\begin{array}{c}\text { Pengaw } \\
\text { asan } \\
\text { Keuanga } \\
\text { ng } \\
\text { Derah } \\
\text { (X5) } \\
\\
(12 \\
\text { Item) }\end{array}$ & $\begin{array}{c}\text { Standar } \\
\text { Akuntansi } \\
\text { Pemerintah } \\
\text { an (X6) } \\
\\
\text { (12 Item) }\end{array}$ & \begin{tabular}{|c|} 
Keterara \\
ndalan \\
dan \\
Ketep \\
atwak \\
uan \\
(Y) \\
\\
(17 \\
Item)
\end{tabular} & & \\
\hline Question 1 & $0.637^{* *}$ & $0.811^{* *}$ & $0.714^{* *}$ & $0.618^{* *}$ & $0.488^{* *}$ & $0.558^{* *}$ & 0.598 & 0.172 & Valid \\
\hline Question 2 & $0.569^{* *}$ & $0.667^{* *}$ & $0.625^{* *}$ & $0.454^{* *}$ & $0.413^{* *}$ & $0.743^{* *}$ & 0.414 & 0.172 & Valid \\
\hline Question 3 & $0.511^{* *}$ & $0.228^{* *}$ & $0.524^{* *}$ & $0.688^{* *}$ & $0.475^{* *}$ & $0.348^{* *}$ & 0.468 & 0.172 & Valid \\
\hline
\end{tabular}




\begin{tabular}{|c|c|c|c|c|c|c|c|c|c|}
\hline Question 4 & $0.517^{* *}$ & $0.610^{* *}$ & $0.714^{* *}$ & $0.743^{* *}$ & $0.644^{* *}$ & $0.771^{* *}$ & \begin{tabular}{l|l|}
0.582 \\
$* * a$
\end{tabular} & 0.172 & Val \\
\hline Question 5 & $0.647^{* *}$ & $0.811^{* *}$ & $0.480^{* *}$ & $0.616^{* *}$ & $0.692^{* *}$ & $0.702^{* *}$ & 0.635 & 0.172 & $\mathrm{Val}$ \\
\hline Question 6 & $0.541^{* *}$ & $0.667^{* *}$ & $0.445^{* *}$ & $0.549^{* *}$ & $0.783^{* *}$ & $0.597^{* *}$ & 0.709 & 0.172 & $v_{i}$ \\
\hline Question 7 & $0.573^{* *}$ & $0.779^{* *}$ & $0.626^{* *}$ & $0.728^{* *}$ & $0.637^{* *}$ & $0.739^{* *}$ & 0.481 & 0.172 & $\mathrm{Va}$ \\
\hline Question 8 & $0.594^{* *}$ & $0.819^{* *}$ & $0.678^{* *}$ & $0.567^{* *}$ & $0.611^{* *}$ & $0.637^{* *}$ & \begin{tabular}{|c|}
0.440 \\
$* *$
\end{tabular} & 0.172 & \\
\hline Question 9 & $0.442^{* *}$ & $0.512^{* *}$ & $0.636^{* *}$ & $0.598^{* *}$ & $0.583^{* *}$ & $0.541^{* *}$ & $\begin{array}{c}0.650 \\
* *\end{array}$ & 0.172 & \\
\hline Question 10 & $0.250^{* * *}$ & $0.722^{* *}$ & $0.652^{* *}$ & $0.607^{* *}$ & $0.454^{* *}$ & $0.599^{* *}$ & 0.395 & 0.172 & $\mathrm{Va}$ \\
\hline Question 11 & $0.255^{* *}$ & & & & $0.452^{* *}$ & $0.587^{* *}$ & 0.703 & 0.172 & $\mathrm{Va}$ \\
\hline Question 12 & $0.283^{* *}$ & & & & $0.783^{* *}$ & $0.446^{* *}$ & 0.676 & 0.172 & $\mathrm{Va}$ \\
\hline Question 13 & & & & & & & 0.693 & 0.172 & Va \\
\hline Question 14 & & & & & & & 0.740 & 0.172 & Val \\
\hline Question 15 & & & & & & & 0.638 & 0.172 & $\mathrm{Val}$ \\
\hline Question 16 & & & & & & & 0.315 & 0.172 & $\mathrm{Va}$ \\
\hline Question 17 & & & & & & & 0.249 & 0.172 & \\
\hline Total & 1 & 1 & 1 & 1 & 1 & 1 & 1 & 1 & \\
\hline
\end{tabular}

**. Correlation is significant at the 0.01 level (2-tailed).

*. Correlation is significant at the 0.05 level (2-tailed).

Keterangan : Tabel $(\mathrm{dk}=130 ; \alpha=2$-tailed $)=0,172$

Sumber data : Data primer yang diolah, 2020 (Output SPSS)

Berdasarkan Tabel 4.8 diketahui

bahwa nilai koefisien korelasi produk moment (r hitung) untuk seluruh variable $\left(\mathrm{X}_{1}\right),\left(\mathrm{X}_{2}\right),\left(\mathrm{X}_{3}\right),\left(\mathrm{X}_{4}\right),\left(\mathrm{X}_{5}\right),\left(\mathrm{X}_{6}\right)$, dan Variabel (Y) dari masing-masing item pertanyaan memiliki $\mathrm{r}$ hitung lebih dari $\mathrm{r}$ table ( $\mathrm{r}$ hitung > 0,172), yang berarti seluruh indikator butir pertanyaan dari variabel dinyatakan valid, atau nilai signifikansi lebih kecil dari alpha $(\alpha=$ $0,05)$.

\section{Uji Reliabilitas}

Realibilitas sesuatu instrumen cukup dapat dipercaya untuk digunakan sebagai alat pengumpul data instrumen yang baik dan andal bila memiliki koefisien realibilitas sebesar 0,6 (60\%) atau lebih, atau Cronbach Alpha $\left(\mathbf{r}_{11}\right)$ lebih besar dari > 0,6 maka dinyatakan reliabel.

Tabel 4.15

Hasil Uji Reliabilitas

\begin{tabular}{|l|c|c|c|}
\hline \multicolumn{1}{|c|}{ Variabel } & $\begin{array}{c}\text { Alpha } \\
\text { Cronb } \\
\text { ach }\end{array}$ & $\begin{array}{c}\text { Nilai } \\
\text { Kritis }\end{array}$ & Keterangan \\
\hline $\begin{array}{l}\text { Komitmen } \\
\text { Organisasi }\end{array}$ & 0,694 & 0,6 & Reliabel \\
\hline Kapasitas SDM & 0,868 & 0,6 & Reliabel \\
\hline $\begin{array}{l}\text { Pengendalian } \\
\text { Internal Akuntansi }\end{array}$ & 0,803 & 0,6 & Reliabel \\
\hline $\begin{array}{l}\text { Pemanfaatan } \\
\text { Teknologi Informasi }\end{array}$ & 0,817 & 0,6 & Reliabel \\
\hline $\begin{array}{l}\text { Pengawasan } \\
\text { Keuangan Daerah }\end{array}$ & 0,826 & 0,6 & Reliabel \\
\hline $\begin{array}{l}\text { Standar Akuntansi } \\
\text { Pemerintahan }\end{array}$ & 0,843 & 0,6 & Reliabel \\
\hline $\begin{array}{l}\text { Keterandalan dan } \\
\text { Ketepatwaktuan }\end{array}$ & 0,839 & 0,6 & Reliabel \\
\hline
\end{tabular}


Pelaporan Keuangan

Akrual

Sumber data : Data primer yang diolah, 2020

(Output SPSS)

Berdasarkan Tabel 4.15 diatas

diketahui bahwa variabel kualitas

Komitmen Organisasi, Kapasitas Sumber

Daya Manusia, Pengendalian Intern

Akuntansi, Pemanfaatan Teknologi

Informasi, Pengawasan Keuangan

Daerah, Standar Akuntansi

Pemerintahan, Keterandalan Dan

Ketepatwaktuan Pelaporan Keuangan

memiliki nilai cronbach alpha yang lebih

tinggi dari 0,6, maka dikatakan reliabel

dan syarat reliabilitas alat ukur terpenuhi.

\section{Uji Asumsi Klasik}

\section{a. Uji Multikolineritas}

Uji multikolinearitas bertujuan

menguji apakah model regresi ditemukan adanya korelasi antar variabel bebas atau independen (Ghozali, 2006). Dalam pengertian sederhana setiap variabel bebas menjadi variabel terikat dan diregresi terhadap variabel bebas lainnya. Multikolinearitas terjadi apabila antar variabel bebas terdapat hubungan yang signifikan. Jadi Nilai tolerance yang rendah sama dengan nilai VIF tinggi (karena VIF $=1 /$ tolerence) dan menunjukan kolinieritas yang tinggi. Nilai cut off yang umum dipakai adalah nilai tolerance $>0,10$ atau sama dengan nilai VIF di atas 10. Model regresi yang baik seharusnya tidak terjadi korelasi antar variabel bebas (independen).

Berikut merupakan hasil pengujian multikolinearitas.

Tabel 4.16

Hasil Uji Multikolinritas

\begin{tabular}{|c|c|c|c|}
\hline \multicolumn{4}{|c|}{ Coefficients ${ }^{a}$} \\
\hline \multirow[b]{2}{*}{ Madel } & & \multicolumn{2}{|c|}{ Collinearity Statistics } \\
\hline & & Tolerance & VIF \\
\hline \multirow[t]{6}{*}{1} & Komitmen Organisasi & .183 & 5.476 \\
\hline & Kapasitas SDM & .933 & 1.072 \\
\hline & $\begin{array}{l}\text { Pengendalian Internal } \\
\text { Akuntansi }\end{array}$ & .129 & 7.775 \\
\hline & $\begin{array}{l}\text { Pemanfaatan Teknologi } \\
\text { Informasi }\end{array}$ & .191 & 5.239 \\
\hline & $\begin{array}{l}\text { Pengawasan Keuangan } \\
\text { Daerah }\end{array}$ & .279 & 3.588 \\
\hline & $\begin{array}{l}\text { Standar Akuntansi } \\
\text { Pemerintahan }\end{array}$ & .367 & 2.726 \\
\hline
\end{tabular}

a. Dependent Variable: Keterandalan Dan Ketepatwaktuan

Sumber data : Data hasil diolah, 2020 (Output SPSS)

Hasil perhitungan nilai tolerance menunjukan semua variabel bebas memiliki nilai tolerance lebih 0,10 . Hasil perhitungan nilai Variance Inflation Factor (VIF) juga menunjukan semua 
variabel bebas memiliki nilai $\mathrm{VIF}<10$. Jadi dapat disimpulkan bahwa tidak ada multikolinearitas antar variabel bebas dalam model regresi

b. Uji Autokorelasi

Uji autokorelasi bertujuan menguji apakah dalam model regresi linier ada korelasi antara kesalahan pengganggu pada periode $\mathrm{t}$ dengan kesalahan pengganggu pada periode $\mathrm{t}-1$ (Ghozali, 2006). Berikut merupakan hasil pengujian autokorelasi. Uji autokorelasi untuk penelitian ini menggunakan Durbin Watson test, dimana dikatakan tidak terjadi autokorelasi jika nilai durbin watson lebih besar dari du dan lebih kecil dari 4-du (du $<\mathrm{dw}<4-\mathrm{du})$. Dari hasil pengolahan diperoleh hasil sebagai berikut:

Tabel 4.17

Hasil Uji Autokorelasi 1 (SPSS)

\begin{tabular}{|c|c|c|c|c|c|}
\hline \multicolumn{6}{|c|}{ Model Summary ${ }^{b}$} \\
\hline Mode & $\mathrm{R}$ & R Square & $\begin{array}{l}\text { Adjusted R } \\
\text { Square } \\
\end{array}$ & $\begin{array}{l}\text { Std. Error of } \\
\text { the Estimate }\end{array}$ & $\begin{array}{l}\text { Durbin- } \\
\text { Watson }\end{array}$ \\
\hline 1 & $.932^{2}$ & .868 & .861 & 2.470 & 1.7 \\
\hline
\end{tabular}

Sumber data : Data hasil diolah, 2020 (Output SPSS)

Tabel 4.18

Hasil Uji Autokorelasi 2

\begin{tabular}{|l|c|c|c|c|c|c|}
\hline \multicolumn{2}{|c|}{$\mathrm{N}=130 \quad \mathrm{k}=6$} & \multicolumn{2}{c|}{$\alpha=0,05$} & & \\
\hline $\mathrm{dw}$ & $\mathrm{dl}$ & $\mathrm{du}$ & $4-\mathrm{dl}$ & $4-\mathrm{du}$ & $\begin{array}{c}\mathrm{du}<\mathrm{dw} \\
<4-\mathrm{du}\end{array}$ & $\begin{array}{c}\text { Tidak } \\
\text { terjadi }\end{array}$ \\
& & & & & $\begin{array}{c}1,729< \\
\text { Autok } \\
\text { orelasi }\end{array}$ \\
\hline
\end{tabular}

Dari tabel di atas dapat diketahui nilai $\mathrm{dw}$ hasil olahan SPSS sebesar 1,744, sedangkan nilai dl dari tabel Durbin Watson $\alpha=0,05$ nilai $\mathrm{dl}=1,698$ dan nilai $\mathrm{du} 1,729$. Oleh karena itu, sesuai rumus $(\mathrm{du}<\mathrm{dw}<4-\mathrm{du}$ ) didapat $(1,729<1,744<2,270)$, sehingga dapat disimpulkan tidak terjadi autokorelasi.

\section{c. Uji Heterokedasitas}

Uji heteroskedastisitas bertujuan menguji apakah dalam model regresi terjadi ketidaksamaan variance dari residual satu pengamatan ke pengamatan yang lain. Jika variance dari residu satu pengamatan ke pengamatan lain tetap, maka disebut homokedastisitas, dan jika berbeda disebut heteroskedastisitas, Pengujian ini menggunakan uji Glejser. Dengan asumsi jika variabel independen signifikan secara 
statistik mempengaruhi variabel dependent (absolute) maka ada indikasi terjadi heteroskedastisitas dan sebaliknya.

Tabel 4.19

Hasil Uji Heterokedasitas

\begin{tabular}{|l|c|c|c|}
\hline \multicolumn{1}{|c|}{ Variabel } & $\begin{array}{c}\text { Nilai } \\
\text { Sig. } \\
\text { Proba } \\
\text { bility }\end{array}$ & $\begin{array}{c}\text { Nilai } \\
\text { Kritis }\end{array}$ & Keterangan \\
\hline $\begin{array}{l}\text { Komitmen } \\
\text { Organisasi }\end{array}$ & 0,311 & 0,05 & Tidak ada \\
\hline Kapasitas SDM & 0,705 & 0,05 & Tidak ada \\
\hline $\begin{array}{l}\text { Pengendalian } \\
\text { Internal } \\
\text { Akuntansi }\end{array}$ & 0,070 & 0,05 & Tidak ada \\
\hline $\begin{array}{l}\text { Pemanfaatan } \\
\text { Teknologi } \\
\text { Informasi }\end{array}$ & 0,569 & 0,05 & Tidak ada \\
\hline $\begin{array}{l}\text { Pengawasan } \\
\text { Keuangan Daerah }\end{array}$ & 0,107 & 0,05 & Tidak ada \\
\hline $\begin{array}{l}\text { Standar } \\
\text { Akuntansi } \\
\text { Pemerintahan }\end{array}$ & 0,148 & 0,05 & Tidak ada \\
\hline $\begin{array}{l}\text { Sumber ata } \\
\text { Sata }\end{array}$ & & & \\
\hline
\end{tabular}

Sumber data : Data hasil diolah, 2020 (Output

SPSS)

Hasil tampilan output SPSS menunjukkan tidak ada satupun variabel independen yang signifikan secara statistik mempengaruhi variabel dependent nilai absolute. Hal ini dilihat dari nilai probabilitasnya (sig) di atas 0,05 ( $\mathrm{sig}>$ 0,05), sehingga dapat disimpulkan tidak terjadi masalah heteroskedastisitas.
Uji normalitas bertujuan untuk menguji apakah dalam model regresi, variabel pengganggu atau residual memiliki distribusi normal. Model regresi yang baik adalah memiliki distribusi data normal atau mendekati normal (Ghozali, 2006). Dalam penelitian ini uji normalitas dilakukan dengan uji statistik yaitu one sample kolmogorov smirnov test. Berikut merupakan hasil pengujian normalitas menggunakan bantuan program SPSS :

Tabel 4.20

Hasil Uji Normalitas

\begin{tabular}{|l|c|c|c|}
\hline \multicolumn{1}{|c|}{ Variabel } & $\begin{array}{c}\text { Asymp } \\
\text {.Sig } \\
(2- \\
\text { tailed })\end{array}$ & $\begin{array}{c}\text { Taraf } \\
\alpha \\
\text { alpha }\end{array}$ & $\begin{array}{c}\text { Keteran } \\
\text { gan }\end{array}$ \\
\hline Komitmen Organisasi & 0,416 & 0,05 & Normal \\
\hline Kapasitas SDM & 0,245 & 0,05 & Normal \\
\hline $\begin{array}{l}\text { Pengendalian Internal } \\
\text { Akuntansi }\end{array}$ & 0,488 & 0,05 & Normal \\
\hline $\begin{array}{l}\text { Pemanfaatan Teknologi } \\
\text { Informasi }\end{array}$ & 0,102 & 0,05 & Normal \\
\hline $\begin{array}{l}\text { Pengawasan Keuangan } \\
\text { Daerah }\end{array}$ & 0,100 & 0,05 & Normal \\
\hline $\begin{array}{l}\text { Standar Akuntansi } \\
\text { Pemerintahan }\end{array}$ & 0,328 & 0,05 & Normal \\
\hline
\end{tabular}




$\begin{aligned} & \text { Keterandalan dan } \\ & \text { Ketepatwaktuan } \\ & \text { Pelaporan Keuangan } \\ & \text { Akrual }\end{aligned}$
$\begin{aligned} & \text { Sumber data : Data primer yang diolah, } 2020 \\ & \text { (Output SPSS) } \\ & \text { Hasil pengujian normalitas data }\end{aligned}$
dengan Uji One Sample Kolmogorof-Smirnov
Test di atas menunjukkan nilai variabel
Komitmen Organisasi, Kapasitas SDM,
Pengendalian Internal Akuntansi,
Pemanfaatan Teknologi Informasi,
Pengawasan Keuangan Daerah, Standar
Akuntansi Pemerintahan, Keterandalan dan
Ketepatwaktuan mempunyai nilai Asymp. Sig
(2-tailed) lebih tinggi dari 0,05, [Asymp.Sig >
0,05 ] Sehingga dikatakan data residual
berdistribusi normal.

\section{Analisis Regresi Berganda}

Analisis regresi pertama dalam penelitian ini dimaksudkan untuk melihat bagaimana pengaruh kapasitas SDM, pemanfaatan TI, pengendalian intern akuntansi terhadap keterandalan pelaporan keuangan. Dengan menggunakan bantuan program SPSS didapatkan hasil sebagai berikut :
Tabel 4.21

Analisis Regresi Berganda

Coefficients $^{\mathrm{a}}$

\begin{tabular}{|c|c|c|c|c|c|}
\hline \multirow[b]{2}{*}{ Model } & \multicolumn{2}{|c|}{$\begin{array}{l}\text { Unstandardized } \\
\text { Coefficients }\end{array}$} & \multirow{2}{*}{\begin{tabular}{|c|}
$\begin{array}{c}\text { Standar } \\
\text { dized } \\
\text { Coefficients }\end{array}$ \\
Beta
\end{tabular}} & \multirow[b]{2}{*}{$\mathrm{t}$} & \multirow[b]{2}{*}{ Sig. } \\
\hline & B & $\begin{array}{l}\text { Std. } \\
\text { Error }\end{array}$ & & & \\
\hline 1 (Constant) & 11.958 & 3.268 & & 3.659 & .000 \\
\hline Komitmen Organisasi & .807 & .126 & .492 & 6.418 & .000 \\
\hline Kapasitas SDM & .094 & .028 & .116 & 3.415 & .001 \\
\hline $\begin{array}{l}\text { Pengendalian Internal } \\
\text { Akuntansi }\end{array}$ & -.199 & .145 & -.126 & -1.376 & .171 \\
\hline $\begin{array}{l}\text { Pemanfaatan Teknologi } \\
\text { Informasi }\end{array}$ & -.122 & .112 & -.081 & -1.083 & .281 \\
\hline $\begin{array}{l}\text { Pengawasan Keuangan } \\
\text { Daerah }\end{array}$ & .237 & .085 & .173 & 2.789 & .006 \\
\hline $\begin{array}{l}\text { Standar Akuntansi } \\
\text { Pemerintahan }\end{array}$ & .793 & .074 & .584 & 10.787 & .001 \\
\hline
\end{tabular}

a. Dependent Variable: Keterandalan Dan

Ketepatwaktuan

Sumber data : Data hasil diolah, 2020 (Output SPSS)

Berdasarkan tabel di atas maka persamaan regresi adalah sebagai berikut:

$\mathrm{Y}=11.958+0,807 \mathrm{X} 1+0,094 \mathrm{X} 2+0,199 \mathrm{X} 3+$ $0,122 \mathrm{X} 4+0,237 \mathrm{X} 5+0,793 \mathrm{X} 6+\mathrm{e}$

Persamaan regresi linier berganda di atas dapat diartikan bahwa: 
1. Konstanta sebesar 11,958 menyatakan bahwa tanpa ada pengaruh dari keenam variabel independen dan faktor lain, maka variabel keterandalan dan ketepatwaktuan pelaporan keuangan (Y) berbasis akrual pada satuan kerja perangkat daerah kabupaten kepulauan tanimbar adalah 11,958.

2. Koefisien regresi variabel Komitmen Organisasi sebesar 0,807 dengan nilai sig. $(0,000<0,05)$ berpengaruh signifikan. Hal ini berarti bahwa setiap terjadi kenaikan Komitmen Organisasi akan meningkatkan keterandalan dan ketepatwaktuan pelaporan keuangan berbasis akrual sebesar 0.807 atau sebesar $80,7 \%$ tanpa dipengaruhi faktor lainnya.

3. Koefisien regresi Kapasitas Sumber Daya Manusia sebesar 0,094 dengan nilai sig. $(0,001<0,05)$ berpengaruh signifikan. Hal ini berarti setiap terjadi kenaikan Pengendalian Internal Akuntansi akan meningkatkan keterandalan dan ketepatwaktuan pelaporan keuangan berbasis akrual sebesar 0.094 atau sebesar 9,4\% tanpa dipengaruhi faktor lainnya.

4. Koefisien regresi Pengendalian Internal Akuntansi sebesar 0,199 dengan nilai sig. $(0,171>0,05)$. atau Ho3: $\beta_{3}=0$ yang berarti tidak ada pengaruh yang signifikan atas Pengendalian Internal Akuntansi terhadap Keterandalan dan Ketepatwaktuan Pelaporan Keuangan berbasis akrual, atau hasil nilai $t_{\text {hitung }}$ sebesar 1,376 lebih kecil dari standar nilai $\mathrm{t}_{\text {tabel }} 1.978(1,376<1.978)$.

5. Koefisien regresi Pemanfaatan Teknologi Informasi sebesar 0,122 dengan nilai sig. $(0,281>0,05)$. atau Ho4: $\beta_{4}=0$ yang berarti tidak ada pengaruh yang signifikan antara Pemanfaatan Teknologi Informasi terhadap Keterandalan dan Ketepatwaktuan Pelaporan Keuangan berbasis akrual, atau hasil nilai $t_{\text {hitung }}$ sebesar 1,083 lebih kecil dari standar nilai $\mathrm{t}_{\text {tabel }} 1.978(1,083<1.978)$.

6. Koefisien regresi Pengawasan Keuangan Daerah bernilai 0,237 dengan nilai sig. $(0,006<0,05)$ berpengaruh signifikan. Hal ini berarti setiap terjadi kenaikan 
Pengawasan Keuangan daerah akan meningkatkan keterandalan dan ketepatwaktuan pelaporan keuangan basis akrual sebesar 0.237 atau sebesar $23,7 \%$ tanpa dipengaruhi faktor lainnya.

7. Koefisien regresi Standar Akuntansi Pemerintahan bernilai 0,793 dengan nilai sig. $(0,001<0,05)$ berpengaruh signifikan. Hal ini berarti setiap terjadi kenaikan Standar Akuntansi Pemerintahan (SAP) akan meningkatkan keterandalan dan ketepatwaktuan pelaporan keuangan basis akrual sebesar 0.793 atau sebesar 79,3 \% tanpa dipengaruhi faktor lainnya.

\section{Uji Kelayakan Model}

\section{a. Uji t (Regresi Parsial)}

Selanjutnya untuk menyakinkan bahwa masing-masing variabel yaitu : Komitmen Organisasi, kapasitas SDM, Pengendalian Internal Akuntansi, pemanfaatan TI, Pengawasan Keuangan Daerah dan Standar Akuntansi Pemerintahan berpengaruh terhadap keterandalan dan ketepatwaktuan pelaporan keuangan berbasis akrual pada pemerintah daerah dilakukan pengujian secara parsial. Dari tabel berikut ini :

Tabel 4.22

\section{Hasil Analisis Parsial (uji t)}

(Dengan Signifikansi $\alpha=5 \%$ )

\begin{tabular}{|l|c|c|c|c|}
\hline \multicolumn{1}{|c|}{ Variabel } & $\begin{array}{c}\text { t. } \\
\text { hitung }\end{array}$ & t. tabel & $\begin{array}{c}\text { Proba. } \\
\text { Sig } \\
\alpha= \\
0,05\end{array}$ & $\begin{array}{c}\text { Keteran } \\
\text { gan }\end{array}$ \\
\hline $\begin{array}{l}\text { Komitmen } \\
\text { Organisasi }\end{array}$ & 6,418 & 1,97867 & 0,000 & $\begin{array}{c}\text { Signifi } \\
\text { kan }\end{array}$ \\
\hline $\begin{array}{l}\text { Kapasitas } \\
\text { SDM }\end{array}$ & 3,415 & 1,97867 & 0,001 & $\begin{array}{c}\text { Signifi } \\
\text { kan }\end{array}$ \\
\hline $\begin{array}{l}\text { Pengendalian } \\
\text { Internal } \\
\text { Akuntansi }\end{array}$ & 1,376 & 1,97867 & 0,171 & $\begin{array}{c}\text { Tidak } \\
\text { Sig }\end{array}$ \\
\hline $\begin{array}{l}\text { Pemanfaatan } \\
\text { Teknologi } \\
\text { Informasi }\end{array}$ & 1,083 & 1,97867 & 0,281 & $\begin{array}{c}\text { Tidak } \\
\text { sig }\end{array}$ \\
\hline $\begin{array}{l}\text { Pengawasan } \\
\text { Keuangan } \\
\text { Daerah }\end{array}$ & 2,789 & 1,97867 & 0,006 & $\begin{array}{c}\text { Signifi } \\
\text { kan }\end{array}$ \\
\hline $\begin{array}{l}\text { Standar } \\
\text { Akuntansi } \\
\text { Pemerintahan }\end{array}$ & 10.78 & 1,97867 & 0,000 & Signifi \\
kan
\end{tabular}

\section{b. Uji F}

Uji $F$ seringkali juga dinamakan dengan analysis of variance. Pengujian ini untuk mengetahui apakah variabel-variabel penjelas yang digunakan dalam model, secara 
bersama-sama mempunyai pengaruh atau tidak terhadap variabel yang ingin dijelaskan dengan menggunakan uji $\mathrm{F}$ test. Pengujian ini dilakukan untuk menguji pengaruh $\mathrm{X}$ independen terhadap Y secara bersamasama.

Tabel 4.23

\section{Hasil Uji F}

\begin{tabular}{|c|c|c|c|c|c|c|}
\hline & \multicolumn{6}{|c|}{ ANOVA ${ }^{b}$} \\
\hline & & $\begin{array}{c}\text { Sum of } \\
\text { Squares }\end{array}$ & $\mathrm{df}$ & Mean Square & $\mathrm{F}$ & $\mathrm{Si}$ \\
\hline \multirow[t]{3}{*}{1} & Regression & 4924.724 & 6 & 820.787 & 134.561 & .1 \\
\hline & Residual & 750.268 & 123 & 6.100 & & \\
\hline & Total & 5674.992 & 129 & & & \\
\hline
\end{tabular}

Sumber data : Data hasil diolah, 2020 (Output SPSS)

Berdasarkan tabel 4.23 tampak bahwa nilai $\mathrm{F}$ hitung sebesar 134,561 lebih besar dari $\mathrm{F}$ tabel sebesar 2,71 dengan angka signifikansi $=0,000<\alpha=0,05$. Hal ini berarti bahwa model penelitian adalah fit atau dengan kata lain ada pengaruh yang signifikan antara Komitmen Organisasi, Kapasitas SDM, Pengendalian Internal Akuntansi pemanfaatan TI, Pengawasan Keuangan daerah dan Standar Akuntansi Pemerintahan terhadap Keterandalan dan Ketepatwaktuan Pelaporan keuangan berbasis Akrual.

\section{c. Koefisien Determinasi}

Uji determinasi adalah uji yang digunakan untuk mengetahui besaran dalam persen pengaruh variabel independen secara keseluruhan terhadap variabel dependen. Dari uji determinasi dihasilkan nilai R2 dapat dilihat dalam tabel sebagai berikut:

Tabel 4.24

\section{Hasil Uji Determinasi}

Model Summary

\begin{tabular}{|l|r|r|r|r|}
\hline Model & \multicolumn{1}{c|}{$\mathrm{R}$} & \multicolumn{1}{c|}{ R Square } & $\begin{array}{c}\text { Adjusted R } \\
\text { Square }\end{array}$ & $\begin{array}{l}\text { Std. Error of } \\
\text { the Estimate }\end{array}$ \\
\hline 1 & $.932^{\mathrm{a}}$ & .868 & .861 & 2.470 \\
\hline
\end{tabular}

a. Predictors: (Constant), Standar Akuntansi Pemerintahan, Kapasitas SDM, Pengawasan Keuangan Daerah, Komitmen Organisasi, Pemanfaatan Teknologi Informasi, Pengendalian Internal Akuntansi

Sumber data : Data hasil diolah, 2020 (Output SPSS)

Berdasarkan hasil uji determinasi diketahui bahwa nilai adjusted $\mathrm{R}$ square sebesar 0,868, yang mengandung arti bahwa $86,8 \%$ variasi besarnya keterandalan dan ketepatwaktuan pelaporan keuangan bisa dijelaskan oleh variasi komitmen organisasi, 
kapasitas SDM, pengendalian internal akuntansi, pemanfaatan TI, pengawasan keuangan daerah. Sedangkan sisanya 13,2\% lainnya dijelaskan oleh variabel lain di luar model.

\section{HASIL PEMBAHASAN}

\section{a. Komitmen Organisasi Terhadap Keterandalan dan Ketepatwaktuan Laporan Keuangan}

Berdasarkan tabel 4.21, diperoleh nilai koefisien regresi Komitmen Organisasi sebesar 0,807. Hal ini menunjukkan bahwa Komitmen Organisasi berpengaruh terhadap keterandalan dan ketepatwaktuan pelaporan keuangan berbasis akrual. Nilai signifikansi Komitmen Organisasi adalah $0,000<0,05$, dengan uji $t_{\text {hitung }}$ sebesar 6,418 lebih besar dari nilai $t_{\text {tabel }}$ $1.978(6,418>1.978)$, yang berarti ada pengaruh signifikan terhadap keterandalan pelaporan keuangan. Komitmen organisasi pada pemerintah daerah kabupaten KKT sangat penting dan diperlukan untuk mencapai laporan yang andal dan tepat waktu, karena akuntansi akrual tidak akan berhasil diterapkan atau membawa manfaat pada dirinya sendiri, melainkan butuh keyakinan dari para pimpinan instansi dan seluruh stakeholders dalam menunjukkan sikap, perilaku, komitmen mereka untuk upaya yang sungguhsungguh dalam penerapan accrual basic demi meningkatkan kepercayaan laporan keuangan kepada publik.

\section{Kapasitas Sumber Daya Manusia Terhadap Keterandalan dan Ketepatwaktuan Laporan Keuangan}

Berdasarkan tabel 4.21, diperoleh nilai koefisien regresi kapasitas SDM sebesar 0,094, dengan nilai signifikansi $0,001<0,05$, nilai uji $t_{\text {hitung }} 3,415$ lebih besar dari nilai $t_{\text {tabel }} 1.978 \quad(3,415>$ 1.978). Hal ini menunjukkan bahwa kapasitas SDM berpengaruh signifikan terhadap keterandalan dan ketepatwaktuan pelaporan keuangan. Logis dari hasil penelitain ini adalah 
ketika seseorang merasa memiliki kapasitas yang dibutuhkan cukup dan luas untuk melaksanakan suatu pekerjaan atau tugas yang menjadi tanggung jawabnya maka ia akan menyelesaikan pekerjaan/tugasnya dengan baik dan lebih cepat

\section{b. Pengaruh Pengendalian Internal} Akuntansi Terhadap Keterandalan dan Ketepatwaktuan Laporan

\section{Keuangan}

Berdasarkan tabel 4.21, diperoleh nilai koefisien regresi pengendalian internal akuntansi 0,199, dengan nilai signifikansi pengendalian intern akuntansi adalah $0,171>0,05$. Hal ini menunjukkan bahwa pengendalian intern akuntansi tidak berpengaruh signifikan terhadap keterandalan dan ketapatwaktuan pelaporan keuangan berbasis akrual. Hasil nilai uji $t_{\text {hitung }}$ 1,376 lebih kecil dari standar nilai $t_{\text {tabel }}$ $1.978(1,376$ < 1.978). Hasil penelitian ini disebabkan karena tingginya volume transaksi, dan banyak Pejabat Penatausahaan Keuangan (PPK) jarang melakukan review secara berkala pada setiap dokumen transaksi, kurangnya kontrol pengeluaran sesuai DPA, otorisasi bukti yang kurang memadai, lemahnya verifikasi yang tepat atas transaksi, serta kurangnya kelengkapan bukti yang valid dan sah dalam buku catatan akuntansi

\section{c. Pengaruh Pemanfaatan Teknologi} Informasi Terhadap Keterandalan dan Ketepatwaktuan Laporan Keuangan

Berdasarkan tabel 4.21, diperoleh nilai koefisien regresi pemanfaatan teknologi informasi 0,122 dengan nilai signifikansi adalah $0,281>0,05$. Hal ini menunjukkan bahwa pemanfaatan teknologi informasi tidak berpengaruh terhadap keterandalan dan ketapatwaktuan pelaporan keuangan berbasis akrual. Hasil nilai uji $t_{\text {hitung }} 1,083$ lebih kecil dari standar nilai $t_{\text {tabel }} 1.978$ $(1,083<1.978)$. Temuan tersebut disebabkan karena ketersediaan komputer belum memadai, teknologi jaringan penghubung internet antar SKPD belum tersedia secara keseluruhan, dukungan bendahara baru untuk menguasai SIMDA masih lemah, dan peralatan yang rusak 
tidak diperbaiki secara tepat pada waktunya.

\section{d. Pengaruh Pengawasan Keuangan Daerah Akuntansi Terhadap Keterandalan dan Ketepatwaktuan Laporan Keuangan}

Berdasarkan tabel 4.21, diperoleh nilai koefisien regresi pengawasan keuangan daerah 0,237 . Nilai signifikansi pengawasan keuangan daerah adalah $0,006<0,05$. Hal ini menunjukkan bahwa pengawasan keuangan daerah berpengaruh signifikan terhadap keterandalan dan ketapatwaktuan pelaporan keuangan berbasis akrual. Nilai uji $t_{\text {hitung }}$ sebesar 2,789 lebih besar dari nilai $\mathrm{t}_{\text {tabel }} 1.978$ $(2,789>1.978)$, yang berarti ada pengaruh signifikan pengawasan keuangan daerah terhadap keterandalan pelaporan keuangan berbasis akrual. Hasil tersebut terlihat bahwa pengawasan keuangan daerah dilokasi Pemerintah Daerah Kabupaten MTB telah dilaksanakan dengan baik, salah satunya melalui bidang aset telah membuat database barang milik daerah dan merekapitulasi hasil laporan serta peninjauan langsung atas obyek dan adanya pengawasan setiap pelaksanaan tugas.

\section{e. Pengaruh SAP Akuntansi Terhadap Keterandalan dan Ketepatwaktuan \\ Laporan Keuangan}

Berdasarkan tabel 4.21, diperoleh nilai koefisien regresi standar akuntansi pemerintahan 0,793. Nilai signifikansi pengawasan keuangan daerah adalah $0,001<0,05$. Hal ini menunjukkan bahwa standar akuntansi pemerintahan berpengaruh signifikan terhadap keterandalan dan ketapatwaktuan pelaporan keuangan berbasis akrual. Hasil nilai uji $t_{\text {hitung }}$ sebesar 10,787 lebih besar dari standar $t_{\text {tabel }} 1.978$ (10,787 > 1.978), yang berarti ada pengaruh signifikan standar akuntansi pemerintahan terhadap keterandalan pelaporan keuangan. Hal ini terjadi karena pemahaman laporan keuangan melalui informasi dalam pernyataan standar akuntansi pemerintahan berbasis 
akrual seperti Informasi Laporan

Neraca, Perubahan Ekuitas, Laporan

Realisasi Anggaran, Arus Kas, Catatan atas laporan Keuangan, Saldo Anggaran Lebih telah dipahami dengan baik secara normatif walaupun belum diuji dalam tahap implementasi, sehingga dengan adanya pemahaman yang jelas tentang komponen Standar Akuntansi Pemerintahan (SAP) berbasis akrual sesuai PP. 71 tahun 2010 di SKPD Kabupaten Kepulauan Tanimbar, maka akan dapat membantu tercapainya keterandalan dan ketepatwaktuan pelaporan keuangan berbasis akrual.

\section{DAFTAR PUSTAKA}

Weygandt, Keiso, et.al. 2016.

Financial Accounting For Business

Decision Making, 7e. John Wiley \& Sons, Inc., 111 River Street, Hoboken, NJ 07030-5774, (201)748- 6011, fax (201)

748-6008, website http://www.wiley.com/go/permissions.

Diawati M. 2015. Faktor yang mempengaruhi Keterandalan Laporan Keuangan Daerah: Suatu Sarana Good Governance Akuntansi Pemerintah.

Sholihin, M 2015 Akuntansi Keuangan Daerah Berbasis Akrual: Penerbit, UPP STIM YKPN, Cetakan Pertama Januari 2015
Romney, M dan Paul J Steinbart. 2014. Sistem Informasi Akuntansi, Edisi 13, Penerbit Salemba Empat.

Mahaputra R. (2014). Analisis Faktor-Faktor yang mempengaruhi Kualitas Informasi Pelaporan Keuangan, Pemerintah Daerah; E-Jurnal Akuntansi Universitas Udayana 8.2 (2014): 230-244 ISSN: 2302-8556..

Primayana, 2014. Pengaruh Kapasitas Sumber Daya Manusia, Pengendalian Intern Akuntansi, Pemanfaatan Teknologi Informasi, Dan Pengawasan Keuangan Daerah Terhadap Keterandaan Pelaporan Keuangan Pemerintahan Daerah(Studi Pada Pemerintahan Daerah kabupaten Buleleng).Jurnal Akuntansi Universitas Pendidikan Ganesha JurusanAkuntansi , Vol 2 No:1.

Sari, dan Banu Winoto.2014.Keterandalan dan Ketepatwaktuan Pelaporan Keuangan Daerah Ditinjau dari Sumber Daya Manusia, Pengendalian Interal dan Pemanfaatan Teknologi Informasi. Universitas Muhammadiyah Surakarta hal 418-425, ISSN : 978-602-70429-1-9.

Tanjung, Amries Rusli dan Edfan Darlis. 2014. Pengaruh Kapasitas Sumber Daya Manusia, Pemanfaatan Teknologi Informasi, dan Pengendalian Intern, terhadap Keterandalan Pelaporan Keuangan Pemerintah Daerah (studi pada Pemerintah Riau). Program Studi Magister Akuntansi Pasca Sarjana Universitas Riau, Vol 9 No 1 April hal 1 $-121$

Eriesta, F. 2013. Pengaruh Sumber Daya Manusia, Teknologi Informasi, Dan Pengendalian Internal Akuntansi terhadap Keandalan dan Ketepatan waktu Pelaporan Keuangan (Studi empiris pada Pemerintahan Daerah 
Provinsi Riau). Fakultas Ekonomi Jurusan Akuntansi Universitas Riau.

COSO.May 2013. Internal Control Integrated Framework, Executive Summary

Desmiyawati dan Nur Azlina. 2012. Pengaruh Kualitas Sumber Daya Manusia, Teknologi Informasi, Dan Pengendalian Internal Akuntansi terhadap Nilai Informasi (Studi empiris pada Pemerintahan Daerah Pasaman Barat). Fakultas Ekonomi Jurusan Akuntansi Universitas Negeri Padang.

Zuliarti. 2012. Pengaruh kapasitas sumber daya manusia, pemanfaatan teknologi informasi, dan pengendalian intern akuntansi terhadap nilai informasi pelaporan keuangan pemerintah daerah: Studi pada pemerintah Kabupaten Kudus. Skripsi. Program Studi Akuntansi.

Rosalin, F 2011. Faktor-faktor yang Mempengaruhi Keandalan dan Timeliness Pelaporan Keuangan Badan Layanan Umum, Studi pada $B L U$ di Kota Semarang.Skripsi Universitas Diponegoro : Semarang.

Hellriegel Don, dan Slocum. 2011. Organizational Behavior 13th : Taxas A\&M University. SouthWestern Cengage Learning, 5191 Natorp Boulevard. New York.
Wilkinson, W. Joseph, Michael J. Cerullo, Vasant Raval, \& Bernard Wong-OnWing. 2000. Accounting Information Systems: Essential Concepts and Applications. Fourth Edition. John Wiley and Sons. Inc

Governmental Accounting Standards Boards (GASB). 1999. Concepts Statement No. 1: Objectives of Financial Reporting in Governmental Accounting Standards Boards Series Statement No. 34: Basic Financial Statement and Management Discussion and Analysis for State and Local Government. Norwalk

Robbins (2007) dan Michael C. Jensen, William H. Meckling. 1976. Theory of the Firm: Managerial Behavior,Agency Costs and Ownership Structur. Journal of Financial Economic. October, 1976, V. 3, No. 4, pp. 305-360

Spencer, Palan, Shane Mc,(2007). Glinow dalam Buyung (2007:37) ability the natural aptitudes and learned capabilities required to successfullycomplete a task Underlying Characteristic http://infodanpengertian.blogspot.co.i $\underline{d / 2015 / 04 /}$

Ghozali, Imam. 2006. Aplikasi Analisis Multivariat dengan Program SPSS, cetakan 4, Edisi Satu, Badan Penerbit Universitas Diponegoro, Semarang 
